\title{
A Synbiotic Mixture Ameliorates Depressive Behavior Induced by Dexamethasone or Water Avoidance Stress in a Mouse Model
}

\author{
Fare Modelinde Deksametazon ile İndüklenen Depresif Davranışı veya \\ Sudan Kaçınma Stresini İyileştiren Sinbiyotik Bir Karışım
}

\author{
(D) Azadeh MESRIPOUR*, (D) Pooya RAKHSHANKHAH \\ Isfahan University of Medical Sciences, School of Pharmacy and Pharmaceutical Sciences, Department of Pharmacology and Toxicology, Isfahan, Iran
}

\begin{abstract}
Objectives: Disruption of the hypothalamic-pituitary-adrenal axis by stress and glucocorticoid drugs is a major cause of depression. The benefits of probiotics may extend to systems beyond the gastrointestinal tract, i.e., the central nervous system. Therefore, the effect of a synbiotic (probiotic + prebiotic) mixture on dexamethasone (Dex) and stress-induced depression was investigated.

Materials and Methods: Male albino mice were used, the forced swimming test (FST) measured despair, and the sucrose preference test measured anhedonia. The synbiotic regimen $\left(12.5 \times 10^{6} \mathrm{CFU}\right)$ was supplemented in drinking water for 7 days. Dex was administered subcutaneously either in a single dose on the test day or for 7 days. Water avoidance stress (WAS) was induced for 1 hour each day for 4 days.

Results: Drinking the synbiotic reduced immobility time during the FST ( $54 \pm 7 \mathrm{sec}$ vs. $111 \pm 6 \mathrm{sec}$ in the control water group, p<0.001). Dex injection significantly increased the immobility time (single dose: $166 \pm 6 \mathrm{sec}$ and 7 days: $174 \pm 9 \mathrm{sec}$ ) compared with the control groups, while adding the synbiotic to their drinking water reduced it (single dose: $81 \pm 6.6 \mathrm{sec}$, and 7 days: $84 \pm 14 \mathrm{sec}$ ), indicating that the synbiotic reversed Dex-induced depression. WAS increased the immobility time $(148 \pm 11 \mathrm{sec}$ vs. sham $99 \pm 6 \mathrm{sec}, \mathrm{p}<0.001)$ in the FST test. When the synbiotic treatment was added following WAS, the immobility time decreased $(81 \pm 6.5 \mathrm{sec})$. The synbiotic groups also had a higher sucrose preference percentage.

Conclusion: The synbiotic mixture prevented the effects of WAS, acute or sub-acute Dex-induced depression in mice. Therefore, probiotics might be useful and safe supplements to prevent depression related to stress or glucocorticoid therapies, a phenomenon that deserves further evaluation. Key words: Probiotics, depression, forced swimming test, glucocorticoid, stress
\end{abstract}

ÖZ

Amaç: Hipotalamik-hipofiz-adrenal eksenin stres ve glukokortikoid ilaçlarla bozulması, depresyonun başlıca nedenidir. Probiyotiklerin faydaları, gastrointestinal sistemin ötesindeki sistemlere, yani merkezi sinir sistemine kadar uzanabilir. Bu nedenle, bir sinbiyotik (probiyotik + prebiyotik) karışımın deksametazon (Dex) ve stres kaynaklı depresyon üzerindeki etkisi araştırıldı.

Gereç ve Yöntemler: Erkek albino fareler kullanıldı, zorlu yüzme testi (FST) umutsuzluğu, sükroz tercih testi ise anhedoniyi ölçmek için kullanıldı.

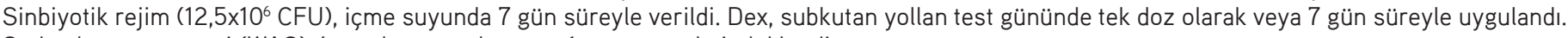
Sudan kaçınma stresi (WAS) 4 gün boyunca her gün 1 saat süreyle indüklendi.

Bulgular: Sinbiyotik içilmesi FST'de hareketsizlik süresini azalttı (kontrol su grubunda $54 \pm 7$ sn'ye karşılık 111 \pm 6 sn, p<0,001). Dex enjeksiyonu, kontrol gruplarına kıyasla hareketsizlik süresini (tek doz: $166 \pm 6$ sn ve 7 gün: $174 \pm 9$ sn) önemli ölçüde artırırken, sinbiyotiklerin içme suyuna eklenmesi ise hareketsizlik süresini azalttı (tek doz: $81 \pm 6,6$ sn ve 7 gün: $84 \pm 14$ sn). Bu, sinbiyotik uygulamasının Dex kaynaklı depresyonu tersine çevirdiğini gösterdi. WAS, FST testinde hareketsizlik süresini $(148 \pm 11$ sn karşı sham grubunda $99 \pm 6$ sn, p<0,001) artırmıştır. WAS'nin ardından sinbiyotik tedavi eklendiğinde, hareketsizlik süresi azaldı (81 26,5 saniye). Sinbiyotik gruplar ayrıca daha yüksek bir sükroz tercih yüzdesine sahipti. Sonuç: Sinbiyotik karışım, farelerde WAS'nin etkilerini, akut veya subakut Dex kaynaklı depresyonu önlemiştir. Bu nedenle probiyotikler, stres veya glukokortikoid tedavileriyle ilişkili depresyonu önlemek için yararlı ve güvenli takviyeler olarak daha fazla değerlendirmeyi hak etmektedirler. Anahtar kelimeler: Probiyotikler, depresyon, zorlu yüzme testi, glukokortikoid, stres

*Correspondence: a_mesripour@yahoo.com, Phone: +00983137927089 ORCID-ID: orcid.org/0000-0003-3150-5581

Received: 25.09.2019, Accepted: 28.11.2019

Turk J Pharm Sci, Published by Galenos Publishing House. 


\section{INTRODUCTION}

Probiotics are defined as "living microorganisms, which when administered in adequate amounts induce beneficial effects on the host". Gut bacterial microorganisms are present as 2 dominant phyla, Bacteroidetes and Firmicutes, ${ }^{1}$ while Bifidobacteria, Lactobacillus, and Bacteroides types represent the most important beneficial probiotics. ${ }^{2}$ Various lines of evidence suggest that probiotics have therapeutic importance in the treatment of several gastrointestinal (GI) disorders, such as inflammatory bowel disease, diarrhea, and irritable bowel syndrome. ${ }^{3}$ More recently, it has been advocated that the effects of probiotic bacteria may extend to systems beyond the Gl tract, i.e., central nervous system (CNS) disorders. 4,5 Animal studies have also suggested that probiotics could have a modulating role in neuroendocrine and neurochemical responses outside the gut. ${ }^{6}$ In animal depression models, probiotic treatment has proved beneficial. Species of the genus Lactobacillus are especially considered to have an antidepressant effect. ${ }^{7}$ Bifidobacterium infantis relieved depression in rat models of depression, probably via reduction of proinflammatory cytokines and regulation of tryptophan metabolism and CNS neurotransmitters. ${ }^{6.8}$ Prebiotics, such as oligosaccharides, stimulate the proliferation of non-pathogenic intestinal microflora. It has been proven that prebiotics also have neurotropic effects by increasing brain-derived neurotropic factor expression in rats, probably via gut hormones. ${ }^{9}$

The microbiome-gut-brain axis refers to the connection that exists between the intestinal microbiota, the gut, and the CNS.10,11 Additionally, research documents suggest that alteration of the gut microflora in mice affects the hypothalamic-pituitaryadrenal (HPA) axis reaction to stress ${ }^{12,13}$ and anxiety behavior. ${ }^{14}$ Probiotics (L. rhamnosus and L. helveticus) not only prevented the elevation of serum corticosterone and the increase in HPA axis activity following maternal separation in rats but also prevented depressive behavior. That is to say, probiotic organisms can adjust HPA axis dysregulation induced by early life stress. ${ }^{15}$ The importance is that there is high comorbidity between $\mathrm{Gl}$ functional illnesses and stress-related psychiatric illnesses, such as anxiety and depression.16 On the other hand, pathogenic bacteria in rodents could cause anxiety-like behaviors, mediated through the vagal afferent nerves. ${ }^{17}$

Depression is often related to stress, possibly because a hypersensitive HPA axis results in chronically elevated cortisol levels as well as cortisol release in response to lower levels of stress. ${ }^{18}$ Synthetic glucocorticoids (GC) are widely used to treat various allergic, inflammatory, and autoimmune disorders. These drugs may induce adverse psychiatric effects (also known as steroid-induced psychosis), including depressed mood. ${ }^{19}$ Furthermore, administration of dexamethasone (Dex) and corticosterone have produced depression-like behaviors in animal models. ${ }^{20,21}$ Previously, the antidepressant effects of a synbiotic [synonym (Syn); probiotic + prebiotic] mixture was proved in an animal model of depression. ${ }^{22}$ The mixture was chosen on the basis that Lactobacilli and Bifidobacteria have antidepressant effects in animal studies; therefore, a manufactured, premixed product was chosen that comprised these genera and also a prebiotic, fructooligosaccharides.

GCs and stressful life events are risk factors for developing major depression, which is strongly linked to impairments in the HPA axis and serotonin (5-HT) neurotransmission; conversely, the beneficial effects of probiotics on the 5-HT system and HPA axis has been proven. ${ }^{6}, 15$ The primary aim of the following study was to induce depression in mice with a single dose or multiple doses of Dex and then to verify the effect of the Syn cocktail on depressive behavior. The secondary aim was to induce depression with stress in mice and ultimately verify the effect of the Syn cocktail on depressive behavior.

\section{MATERIALS AND METHODS}

\section{Animals}

Male albino mice weighing $25 \pm 2 \mathrm{~g}$ were housed at room temperature $23^{\circ} \mathrm{C} \pm 2^{\circ} \mathrm{C}$ with free access to standard rodent chow and treated or untreated drinking water per the experiment, on a 12-12 h light-dark cycle (lights on at $6 \mathrm{am}$ ). Six animals were housed in each cage, and $24 \mathrm{~h}$ before the test they were placed in the experimental room for acclimatization. The total number of animals used, was 72 , divided in 12 groups of animals each containing 6 animals. All the experiments were performed during 08:00-13:00 in daylight in the pharmacology laboratory. All animal procedures were performed in accordance with guidelines for the Care and Use of Laboratory Animals Issued by The National Ethical Committee (no: IR.MUI. RESEARCH.REC.1398.160). All efforts were made to reduce the number of animals used in each experiment and to minimize animal suffering. Animals were manipulated either by Dex administration or by stress induction.

\section{Drug administration and the Syn cocktail}

Dex $(8 \mathrm{mg} / 2 \mathrm{~mL}$ ampule, Raha Industry, Iran) $250 \mathrm{mcg} / \mathrm{kg}$ was injected SC as single dose 3 hours prior the tests, or $15 \mathrm{mcg} / \mathrm{kg}$ was injected daily for 7 consecutive days and testing performed the following day, while control animals received normal saline. ${ }^{6}$ Dex was freshly prepared in normal saline, and injections were adjusted to a volume of $10 \mathrm{~mL} / \mathrm{kg}$ mouse body weight.

The Syn cocktail was prepared from a premixed product comprising $10^{9} \mathrm{CFU}$ probiotic strains and a prebiotic (Lactobacillus casei, L. acidophilus, L. rhamnosus, L. bulgaricus, Bifidobacterium breve, B. infantis, Streptococcus thermophiles, and Fructooligosaccharides; a product of Zisttakhmir Industry, Iran). Animals had free access to the Syn cocktail solution $12.5 \times 10^{6} \mathrm{CFU} ; 22$ in drinking water that was prepared fresh each day; control animals drank tap water ad libitum. The amount of the Syn cocktail solution or drinking water ingested by the animals was measured daily for 7 days, and the tests were performed on the next day.

\section{Water avoidance stress (WAS)}

WAS was performed in a Plexiglas tank comprising a block affixed in the middle of the floor. The tank was filled with room temperature shallow water $\left(22^{\circ} \mathrm{C}\right)$ within $1 \mathrm{~cm}$ of the top of the 
block. The animals were placed on the block for a period of $1 \mathrm{~h}$ daily for 4 consecutive days. ${ }^{23}$ The group of animals that had WAS and drank tap water throughout the experiment are referred to the WAS group. The animals administered synbiotic cocktail were subjected to WAS either during the first 4 days, referred to as WAS1, or during the last 4 days of ingesting the cocktail, referred to as WAS2.

The sham group consisted of animals that were placed similarly for $1 \mathrm{~h}$ daily for 4 days on the same platform in a waterless container.

\section{Locomotor test}

The first experiment was carried out in order to analyze the animal motor activity in an open arena (Borj Sanat, Iran) that was divided into 16 zones by red beams. Mice were allowed to explore the field for $3 \mathrm{~min}$ by passing through the beams. The zone entries were counted automatically, while rears on hind legs were recorded manually. The sum of zone entries (horizontal exploration) and rears (vertical exploration) were calculated as the total activity for each animal.

\section{Forced swimming test (FST)}

During the FST mice were forced to swim in $25^{\circ} \mathrm{C}$ water in a glass 2-liter beaker (diameter $12.5 \mathrm{~cm}$, depth $12 \mathrm{~cm}$ ) for 6 min. The immobility time was measured during the last $4 \mathrm{~min}$ of the $6 \mathrm{~min}$ trial after habituation was performed within the first $2 \mathrm{~min}$. The immobility time is when no additional activity is observed other than that required to keep the animals' head above the water denoting a phenotype of depression. Swimming behavior, defined as horizontal movement around the beaker involving at least 2 limbs, and climbing behavior, defined as upward movement of the forepaws against the beaker wall, were also recorded. ${ }^{24}$ The experiment was recorded by a camera and analyzed later. After the experiment, the animals were dried carefully to avoid hypothermia and returned to their home cages.

\section{Sucrose preference test}

This test measured another depression phenotype in rodents: Anhedonia. The test was conducted in 3 days: On the first day, two bottles of sucrose solution ( $5 \% \mathrm{w} / \mathrm{v}$ ) were applied in the animals' home cage, and on the second day, one bottle of sucrose solution was replaced with water. After the habituation period, mice had access to 2 bottles containing $100 \mathrm{~mL}$ of sucrose solution and $100 \mathrm{~mL}$ of tap water that was finally measured after $24 \mathrm{~h}$, and the percentage of sucrose preference was calculated according to the sucrose solution and water consumption. A decrease in sucrose preference measured to a level below $65 \%$ was taken as the criterion for anhedonia. ${ }^{25}$

\section{Data processing and statistical analysis}

Results are expressed as group means \pm standard error of the mean (SEM). The results were analyzed by One-Way ANOVA, followed by Tukey's multiple comparison tests, and $p$ values smaller than 0.05 were considered significant. The software programs used for data analysis and graph construction were Excel 2010 and GraphPad Prizm 6.

\section{RESULTS}

\section{Daily food and drink intake and body weight change}

As shown in Table 1, there was no significant difference in food consumption between groups. Drinking was significantly higher in Dex-treated animals that drank the Syn cocktail. The daily Syn consumption was then calculated according to the daily drink intake per body weight, which varied between 4.5 and $8.5 \times 10^{6} \mathrm{CFU} / \mathrm{g}$. There was a great rise in the percent body weight change in Dex-treated mice that drank Syn ( $p<0.001$ vs. control and vs. Dex alone group) and in the WAS2 group that ingested Syn ( $p<0.001$ vs. control and $p<0.05$ vs. WAS group).

Effect of Dex and the synbiotic mixture on depressive behavior As presented in Figure 1A, drinking the Syn cocktail reduced immobility time during the FST, which was significantly different from the control group that drank tap water ( $54 \pm 7 \mathrm{sec}$ vs. $111 \pm 6$ sec, p<0.001). Dex acute or sub-acute injection increased the immobility time $(166 \pm 6 \mathrm{sec}$ and $174 \pm 9 \mathrm{sec}$ respectively, $p<0.001$ compared with their corresponding control groups), which clearly indicated animal depressive behavior. Adding the Syn cocktail to the animals' drinking water significantly reduced their immobility time, indicating that the Syn drink reversed Dex-induced depressant effects. As Figure 1B shows, the Syn mixture significantly increased the swimming time in normal animals $(167 \pm 8 \mathrm{sec}$ vs. water group $93 \pm 5 \mathrm{sec}$, p<0.001) or those Table 1. Daily food intake, fluid intake, Syn ingestion, and percent body weight change

\begin{tabular}{lllll} 
Groups & Daily food intake $\mathrm{mg} / \mathrm{g}$ body weight & Daily fluid intake $\mathrm{mL} / \mathrm{g}$ body weight & Daily synbiotic CFU/g body weight & Body weight increase (\%) \\
\hline Control & $181.6 \pm 18$ & $0.42 \pm 0.01$ & 0 & $2.1 \pm 0.7$ \\
\hline Syn & $168.2 \pm 25$ & $0.36 \pm 0.01$ & $4.5 \times 10^{6}$ & $3.8 \pm 0.4$ \\
\hline Dex & $158 \pm 14$ & $0.5 \pm 0.04$ & 0 & $0.9 \pm 0.7$ \\
\hline Dex + Syn & $197 \pm 23$ & $0.68 \pm 0.05^{*}$ & $8.5 \times 10^{6}$ & $9.9 \pm 1^{* * *, d d d}$ \\
\hline WAS & $132 \pm 5$ & $0.54 \pm 0.03$ & 0 & $2.9 \pm 0.7$ \\
\hline WAS1 + Syn & $178 \pm 22$ & $0.58 \pm 0.03$ & $7.2 \times 10^{6}$ & $4.5 \pm 0.7$ \\
\hline WAS2 + Syn & $173 \pm 24.4$ & $0.56 \pm 0.1$ & $7 \times 10^{6}$ & $7.7 \pm 0.7^{* * *, s}$ \\
\hline
\end{tabular}

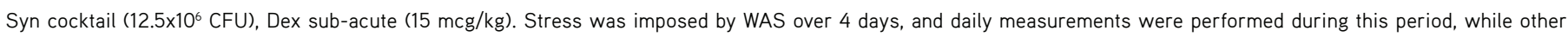

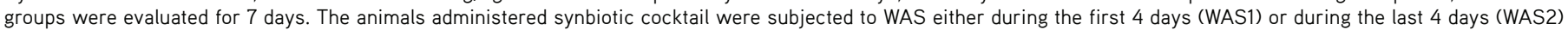

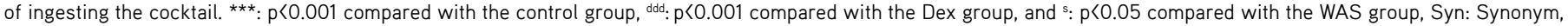
Dex: Dexamethasone, WAS: Water avoidance stress 


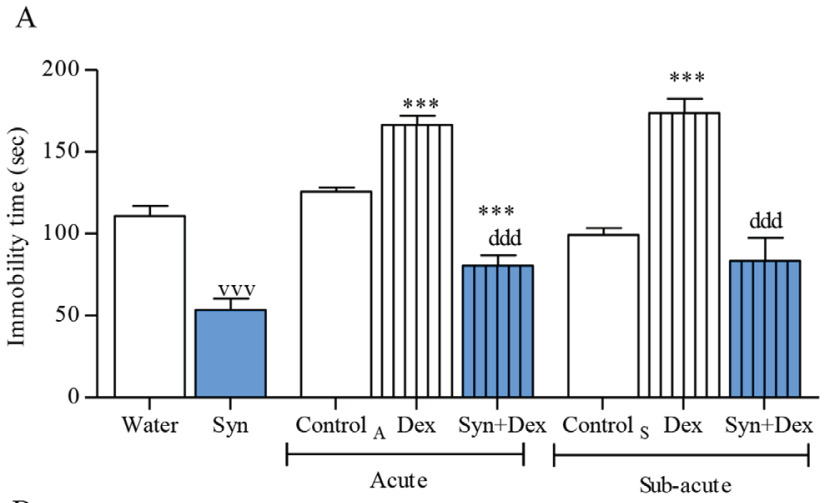

B

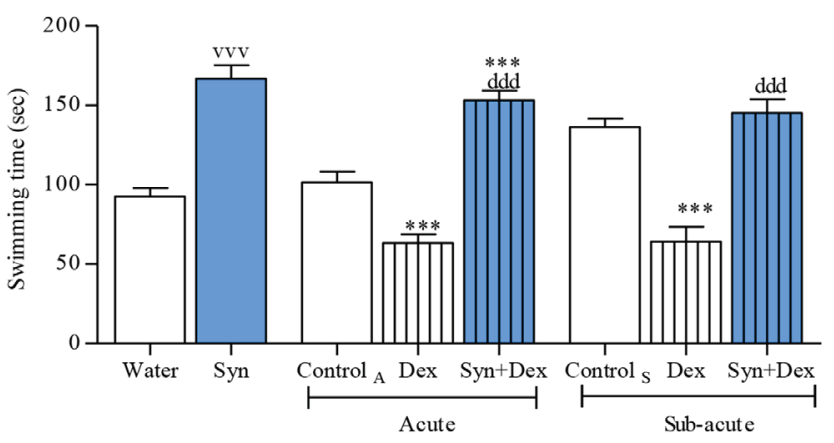

$\mathrm{C}$

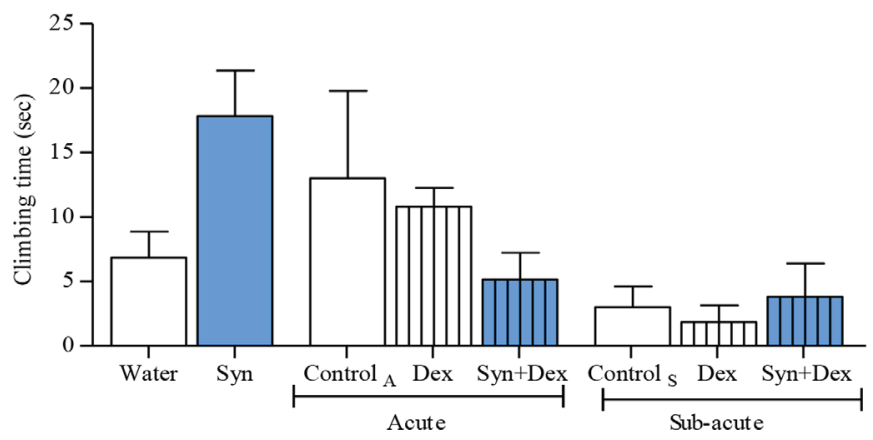

Figure 1. Effect of the synbiotic cocktail and dexamethasone on behavior during the forced swimming test. (A) Immobility time, (B) swimming time, and (C) climbing time. Synbiotic cocktail (Syn; $12.5 \times 10^{6} \mathrm{CFU}$ ) for 7 days, Dex acute $(250 \mathrm{mcg} / \mathrm{kg})$ single dose and control A normal saline, Dex sub-acute $(15 \mathrm{mcg} / \mathrm{kg}$ ) for 7 days and control $\mathrm{S}$ received normal saline. The number of animals in each group was 6 . Results are expressed as group mean \pm SEM and analyzed by ANOVA followed by Tukey's multiple comparison tests. vvv: $p<0.001$ compared with the water drinking group, ${ }^{\star \star *}:$ p $<0.001$ compared with control A or $S$ groups, ${ }^{\text {ddd }}$ : $p<0.001$ compared with Dex alone acute or sub-acute group, Syn: Synonym, Dex: Dexamethasone, SEM: Standard error of the mean

treated with Dex (acute $153 \pm 6 \mathrm{sec}$ and subacute $145 \pm 8.5 \mathrm{sec}$, p<0.001 compared with their corresponding Dex alone groups). Climbing behavior was not significantly different among the various groups (Figure 1C). Table 2 shows the results of the sucrose preference test, which were in line with the FST results. By adding the Syn mixture to drinking water sucrose preference was increased to $82 \%$, while Dex acute or subacute treatments reduced the preference for sucrose to levels under $60 \%$, i.e., no preference of the sucrose solution over water, which indicates anhedonia in mice. Adding the Syn mixture to the drinking water clearly increased the sucrose preference in Dex acute and subacute groups. As shown in Table 3, the animals' locomotor activity in the open arena was not noticeably different between the groups.

Effect of WAS and the synbiotic mixture on depressive behavior Figure 2A shows that exposing the animals to WAS increased immobility time during the FST $(148 \pm 11 \mathrm{sec}$, vs. sham group $99 \pm 6 \mathrm{sec}, \mathrm{p}<0.001)$, which indicated animal despair behavior. Adding the Syn mixture to drinking water reduced immobility time in the WAS1 group $(81 \pm 6.5 \mathrm{sec}, \mathrm{p}<0.001$ compared with WAS alone), but the Syn cocktail was not effective in the WAS2 group $(143 \pm 6 \mathrm{sec})$. This may indicate that the Syn mixture was not able to prevent the stress- induced rise in immobility during the FST. As shown in Figure 2B, C, in the WAS group, swimming time and climbing time were significantly lower than in the sham group. Adding the Syn cocktail to drinking water increased the swimming time significantly (Figure $2 \mathrm{~B}$ ) in the WAS1 group $(142 \pm 18 \mathrm{sec}$, vs. the WAS alone group $68 \pm 10 \mathrm{sec}$, p (0.001), while climbing was lower than in the sham group (Figure 2C). The sucrose preference test results were parallel to the FST results (Table 2). As shown in the table, WAS reduced the sucrose preference to $59 \%$, while in the sham group it was $84 \%$. Meanwhile, adding the Syn mixture in the WAS1 group increased the sucrose preference to $90 \%$, while it was $60 \%$ in the WAS2 group. Animals' locomotor activity in the open arena was not noticeably different between the various groups (Table $3)$.

\section{DISCUSSION}

Our results showed for the first time that a Syn mixture was able to remedy and prevent Dex-induced depression in mice during FST, which was confirmed by the sucrose preference test. We also observed that the Syn mixture treated depression induced by WAS1, but it was not useful to prevent depression induced by WAS2. The sucrose preference test also showed parallel results, as anhedonia was treated following ingestion of Syn after WAS1, but it did not prevent anhedonia induced by WAS2.

Changes in body weight showed that Dex reduced body weight, although the magnitude of the reduction did not reach a significant level. As in humans, GCs showed a powerful catabolic effect on experimental animals. ${ }^{26}$ Body weight increased in animals that ingested the Syn mixture, but the increase was not statistically significant, and there was no noticeable rise in their food consumption. It has been proven that different Lactobacillus species could induce different effects on weight depending on the host. ${ }^{27}$ In addition, certain Lactobacillus species, along with other bacterial species, have been associated with weight gain and obesity. ${ }^{27}$ Therefore, the Lactobacillus present in the cocktail may have, at least in part, caused the weight gain. Wang and colleagues have demonstrated the opposite result, in their study L. paracasei, L. rhamnosus, and B. animalis were associated with weight reduction in high-fat-diet fed mice. ${ }^{28}$ However, when the Syn cocktail was consumed following Dex treatment or WAS, it caused a significant body weight gain, and to some extent, greater food intake. Various mechanisms could 
A
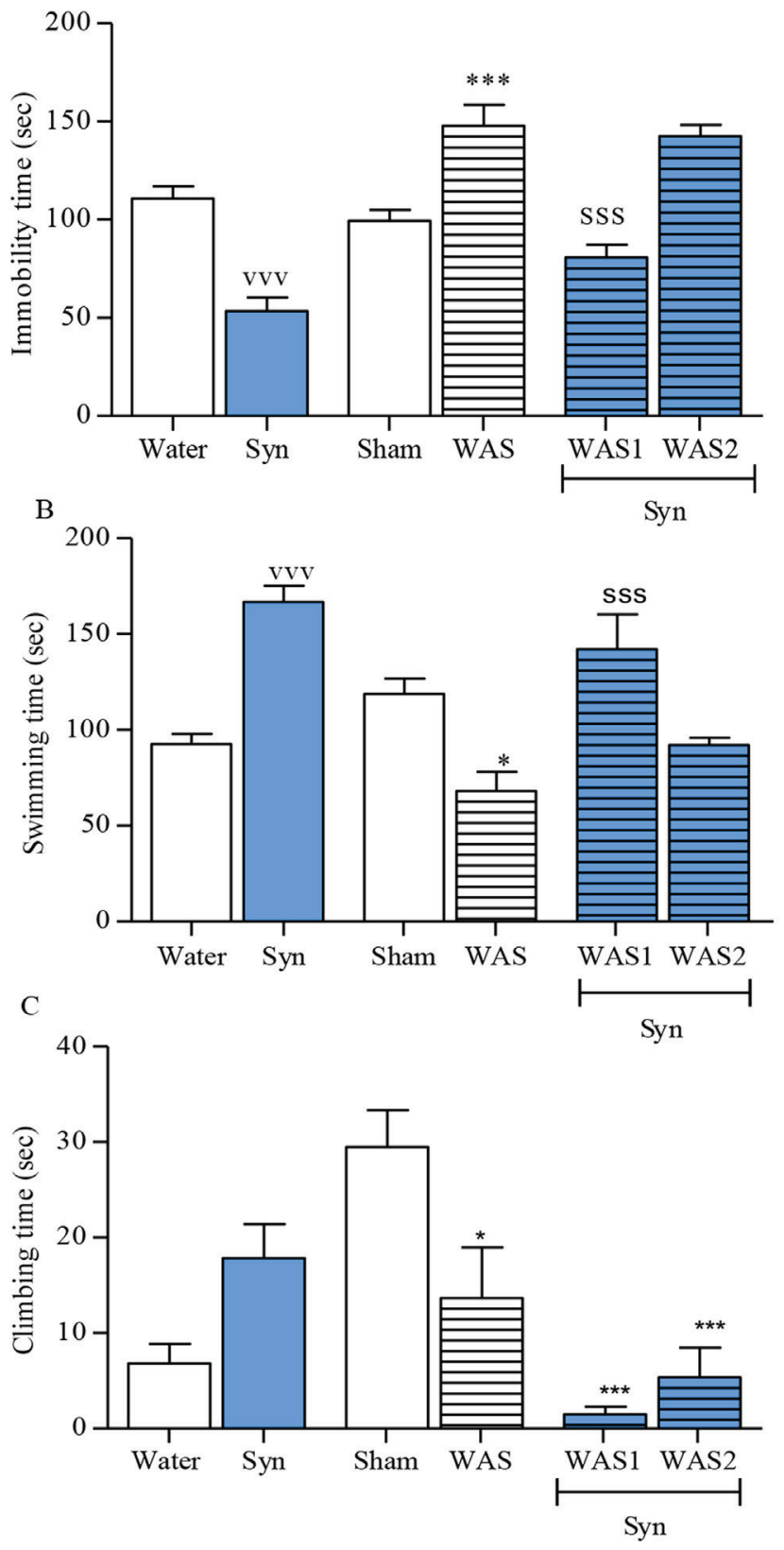

Figure 2. Effect of the synbiotic cocktail and stress on behavior during the forced swimming test. (A) The immobility time, (B) the swimming time, and (C) the climbing time. Syn cocktail $\left(12.5 \times 10^{6} \mathrm{CFU}\right)$ for 7 days. Stress was imposed by WAS during 4 days. The sham group animals were placed in a waterless container. The animals administered synbiotic cocktail were subjected to WAS either during the first 4 days (WAS1) or during the last 4 days (WAS2) of cocktail ingestion. The number of animals in each group was 6 . Results are expressed as group mean \pm SEM and analyzed by ANOVA followed by Tukey's multiple comparison tests. ${ }^{v v}$ : $p<0.001$ compared with the water drinking group, ${ }^{*}: p<0.05,{ }^{* * *}: p<0.001$ compared with the sham group, sss: $p<0.001$ compared with WAS alone group. Syn: Synonym, Dex: Dexamethasone, WAS: Water avoidance stress, SEM: Standard error of the mean

have caused weight gain, apart from the cocktail, and increased food consumption could also have been responsible in these groups. Fructooligosaccharides are composed of fructose units
Table 2. Sucrose preference test results

\begin{tabular}{llll} 
Groups & $\begin{array}{l}\text { Sucrose } \\
\text { preference } \\
(\%)\end{array}$ & Groups & $\begin{array}{l}\text { Sucrose } \\
\text { preference } \\
(\%)\end{array}$ \\
\hline Water & 65 & Sham & 84 \\
\hline Syn & 82 & WAS & 59 \\
\hline Control (acute) & 65 & WAS1 + Syn & 90 \\
\hline Dex (acute) & 53 & WAS2 + Syn & 60 \\
\hline Control (sub-acute) & 75 & Dex (acute) + Syn & 95 \\
\hline Dex (sub-acute) & 58 & Dex (sub-acute) + Syn & 72 \\
\hline
\end{tabular}

Syn cocktail $\left(12.5 \times 10^{6} \mathrm{CFU}\right)$ for 7 days, Dex acute $(250 \mathrm{mcg} / \mathrm{kg})$ single dose and or sub-acute $(15 \mathrm{mcg} / \mathrm{kg})$ for 7 days and the control groups received normal saline. Stress was imposed by WAS over 4 days. The animals administered synbiotic cocktail were subject to WAS either during the first 4 days (WAS1) or during the last 4 days (WAS2) of ingesting the cocktail. The sham group animals were placed in a waterless container. The number of animals in each group was 6 . Percentage of sucrose preference=(sucrose consumption/sucrose consumption + water consumption) x100. Syn: Synonym, Dex: Dexamethasone, WAS: Water avoidance stress

Table 3. Total activity during the locomotor test

\begin{tabular}{llll} 
Groups & $\begin{array}{l}\text { Total } \\
\text { activity } \\
\text { (count) }\end{array}$ & Groups & $\begin{array}{l}\text { Total } \\
\text { activity } \\
\text { (count) }\end{array}$ \\
\hline Water & $165 \pm 16$ & Sham & $230 \pm 14$ \\
\hline Syn & $192 \pm 17$ & WAS & $213 \pm 7$ \\
\hline Control (acute) & $173 \pm 12$ & WAS1 + Syn & $179 \pm 16$ \\
\hline Dex (acute) & $155 \pm 6$ & WAS2 + Syn & $171 \pm 20$ \\
\hline Control (sub-acute) & $170 \pm 13$ & Dex (acute) + Syn & $199 \pm 14$ \\
\hline Dex (sub-acute) & $150 \pm 15$ & Dex (sub-acute) + Syn & $188 \pm 13$ \\
\hline
\end{tabular}

Syn cocktail $\left(12.5 \times 10^{6} \mathrm{CFU}\right)$ for 7 days, Dex acute $(250 \mathrm{mcg} / \mathrm{kg})$ single dose and or sub-acute $(15 \mathrm{mcg} / \mathrm{kg})$ for 7 days, and the control groups received normal saline. Stress was imposed by WAS during 4 days. The animals administered synbiotic cocktail were subject to WAS either during the first 4 days (WAS1) or during the last 4 days (WAS2) of ingesting the cocktail. The sham group was placed in a waterless container. Total activity count during locomotor test=(horizontal + vertical) exploration. The number of animals in each group was 6 . Results are expressed as group mean \pm SEM and analyzed by ANOVA followed by Tukey's multiple comparison test. The differences between various groups did not reach statistical significance. Syn: Synonym, Dex: Dexamethasone, WAS: Water avoidance stress, SEM: Standard error of the mean

that occur naturally in plants, and they induce a low level of sweetness, although they are calorie free and non-cariogenic. ${ }^{29}$ It seems unlikely that fructooligosaccharides were responsible for the observed weight gain.

During the FST, when the mouse is placed in the water, the animal gradually loses hope of escaping the stressful environment; thus, the immobility time reflects a measure of "behavioral despair". FST is not only a reliable tool in drug discovery in industrial settings where a high extent of screening of new compounds is essential but also in complementary depression medicine research. ${ }^{30}$ In the same trend as previous results, the Syn cocktail presented antidepressant effects in mice by reducing immobility time. ${ }^{22}$ Evidently the selective 5-HT reuptake inhibitor (SSRI) drug, fluoxetine decreases immobility time while increasing swimming behavior. ${ }^{24}$ The 5-HT level was not measured in our experiment, but the changes during the FST with the Syn mixture were similar to 
those induced by the SSRI drug, since the swimming time was augmented, which might be related to the serotonergic system. This statement is supported by a previous study that reported a decrease in the 5-hydroxyindoleacetic acid level in the frontal cortex following treatment of rats with $B$. infantis, indicating that 5-HT degradation was reduced, possibly due to decreased monoamine oxidase activity. ${ }^{6}$

Single dose and long-term Dex administration induced despair behavior during the FST, and anhedonia was deduced since the sucrose preference was reduced to levels under $60 \%$. This was proven earlier, since it was shown that Dex dose-dependently increased the immobility time during the FST. ${ }^{20}$ Addition of the Syn mixture reduced the immobility time in the FST not only when Dex was injected as single dose but also when it was administered for 7 days. This showed that the Syn mixture could have preventive effects on Dex-induced mental disorders. It has been shown previously that repeated corticosterone injections induce depressive behavioral and dysregulation of the HPA axis, since corticosterone could have blocked the HPA axis response that normally occurs after the animal is dropped in the water during FST testing. ${ }^{31,32} \mathrm{GC}$ receptor function may be impaired or it may become resistant to GCs in depression, thus causing HPA axis hyperactivity in depression, thereby causing high GC levels. ${ }^{33}$ Evidently, the gut microbiota plays an imperative role in the regulation and development of the HPA axis. ${ }^{7}$ Thus it could be deduced that consumption of the Syn mixture has a high likelihood of preventing HPA alterations induced by Dex and therefore preventing its depressive behavior in the FST. In order to further evaluate the possible effect of probiotics on HPA alteration-induced depression, a stress model was accomplished. WAS is a well-recognized method that represents an effective psychological stressor with conspicuous boosts of adrenocorticotropic hormone and corticosterone within 30 min. $^{34}$ We observed that WAS induced despair behavior by increasing immobility time during the FST; meanwhile, anhedonia was assumed since there was no preference for sucrose over water consumption. During WAS1, when the Syn formulation was started with WAS and continued for 3 additional days, depressive symptoms went away in mice. However, during WAS2, which was imposed on the last 4 days of Syn formula ingestion, beneficial effects were not observed. On the other hand, Ait-belgnaoui and colleagues observed that a 2-week treatment with a probiotic formulation (consisting of $L$. helveticus R0052 and $B$. longum R0175) mitigated the HPA axis and autonomic nerve system response to WAS, as revealed by decreased levels of corticosterone and noradrenaline in stressed mouse plasma. ${ }^{23}$ They administered the probiotic mixture orally at a concentration of $10^{9} \mathrm{CFU} /$ day to C57Bl6 mice and induced WAS at the end of this period. In our observational study, corticosterone plasma levels were not assessed; however, behavior studies showed interestingly that the Syn mixture could overcome depression induced by WAS but it could neither prevent it during FST nor during the sucrose preference test in mice. In addition, WAS caused a decrease in the swimming time, and Syn ingestion significantly increased it in the WAS1 experiment. It has been proven previously that swimming during the FST is related to the serotonergic pathway; ${ }^{24}$ therefore, the Syn mixture may have overcome WAS-induced depression by altering the serotonergic system. This belief is supported by previous studies showing that chronic stress causes depression-related behavior through neurotransmitter changes in the CNS, suppression of hippocampal neurogenesis, and HPA axis dysfunction, which manipulates 5-HT activity and exacerbates the effects of stress. ${ }^{35}$ Brain-gut communication is achieved by various interrelated systems, for example, through the hormones of the HPA axis, through neural pathways of the autonomic nervous system (which involves the vagus nerve and the adrenergic system), or through immune cytokines. ${ }^{36}$

It has been shown that various forms of stress change the composition of the intestinal microbiota in animals, for example, in one study, after a stressful experience the number of Lactobacilli and Bifidobateria in the gut were reduced. ${ }^{37}$ Conversely, treatment with probiotic bacteria reduced the detrimental effects of stress. ${ }^{8}$ Therefore, our results were in favor of previous reports of a high amount of comorbidity between CNS and GI disorders, where it has been reported that large number of those being treated for irritable bowel syndrome also suffer from psychiatric illness. ${ }^{38}$

\section{CONCLUSION}

This behavioral study clearly revealed that the Syn formulation can prevent depression induced by the GC drug Dex. In addition, it could remedy WAS-induced depression. Although extrapolating animal data to humans should be done judiciously, probiotics that could be easily inserted in the diet could be a useful alternative therapy in stress- or GC-related depression, while avoiding the harmful side effects of common antidepressants. The Syn effect on depressive behavior may be related to a number of aspects, including ameliorating GC- or stress-induced alterations in stress hormones, brain plasticity, and neurogenesis, which warrants further studies.

\section{ACKNOWLEDGMENTS}

This work was supported by the School of Pharmacy and Pharmaceutical Sciences Research Council (grant no: 398160; May 8, 2019), Isfahan University of Medical Sciences.

Conflicts of interest: No conflict of interest was declared by the authors. The authors alone are responsible for the content and writing of the paper.

\section{REFERENCES}

1. Hemarajata P, Versalovic J. Effects of probiotics on gut microbiota: mechanisms of intestinal immunomodulation and neuromodulation. Therap Adv Gastroenterol. 2013;6:39-51.

2. Round JL, Mazmanian SK. The gut microbiota shapes intestinal immune responses during health and disease. Nat Rev Immunol. 2009;9:313323.

3. Floch MH, Walker WA, Guandalini S, Hibberd P, Gorbach S, Surawicz C, Sanders ME, Garcia-Tsao G, Quigley EM, Isolauri E, Fedorak RN, Dieleman LA. Recommendations for probiotic use--2008. J Clin Gastroenterol. 2008;42(Suppl 2):S104-108. 
4. Dinan TG, Cryan JF. Melancholic microbes: a link between gut microbiota and depression? Neurogastroenterol Motil. 2013;25:713-719.

5. Cerdó T, Ruíz A, Suárez A, Campoy C. Probiotic, Prebiotic, and Brain Development. Nutrients. 2017;9:1247.

6. Desbonnet L, Garrett L, Clarke G, Bienenstock J, Dinan TG. The probiotic Bifidobacteria infantis: An assessment of potential antidepressant properties in the rat. J Psychiatr Res. 2008;43:164-174.

7. Wang $\mathrm{Y}, \mathrm{Kasper} \mathrm{LH}$. The role of microbiome in central nervous system disorders. Brain Behav Immun. 2014;38:1-12.

8. Desbonnet L, Garrett L, Clarke G, Kiely B, Cryan JF, Dinan TG. Effects of the probiotic Bifidobacterium infantis in the maternal separation model of depression. Neuroscience 2010;170:1179-1188.

9. Savignac HM, Corona G, Mills H, Chen L, Spencer JP, Tzortzis G, Burnet PW. Prebiotic feeding elevates central brain derived neurotrophic factor, $\mathrm{N}$-methyl-d-aspartate receptor subunits and d-serine. Neurochem Int. 2013;63:756-764.

10. Cryan JF, O'Mahony SM. The microbiome-gut-brain axis: from bowel to behavior. Neurogastroenterol Motil. 2011;23:187-192.

11. Forsythe P, Sudo N, Dinan T, Taylor VH, Bienenstock J. Mood and gut feelings. Brain Behav Immun. 2010;24:9-16.

12. Sudo N, Chida Y, Aiba Y, Sonoda J, Oyama N, Yu XN, Kubo C, Koga Y. Postnatal microbial colonization programs the hypothalamic-pituitaryadrenal system for stress response in mice. J Physiol. 2004;558(Pt 1):263-275.

13. Neufeld KM, Kang N, Bienenstock J, Foster JA. Reduced anxietylike behavior and central neurochemical change in germ-free mice. Neurogastroenterol Motil. 2011;23:255-264, e119.

14. Diaz Heijtz R, Wang S, Anuar F, Qian Y, Björkholm B, Samuelsson A, Hibberd ML, Forssberg H, Pettersson S. Normal gut microbiota modulates brain development and behavior. Proc Natl Acad Sci U S A. 2011;108:3047-3052.

15. Gareau MG, Jury J, MacQueen G, Sherman PM, Perdue MH. Probiotic treatment of rat pups normalises corticosterone release and ameliorates colonic dysfunction induced by maternal separation. Gut. 2007;56:1522-1528.

16. Gros DF, Antony MM, McCabe RE, Swinson RP. Frequency and severity of the symptoms of irritable bowel syndrome across the anxiety disorders and depression. J Anxiety Disord. 2009;23:290-296.

17. Goehler LE, Gaykema RP, Opitz N, Reddaway R, Badr N, Lyte M. Activation in vagal afferents and central autonomic pathways: Early responses to intestinal infection with Campylobacter jejuni. Brain Behav Immun. 2005;19:334-344.

18. Dean J, Keshavan M. The neurobiology of depression: An integrated view. Asian J Psychiatr. 2017;27:101-111.

19. Brown ES, J Woolston D, Frol A, Bobadilla L, Khan DA, Hanczyc M, Rush AJ, Fleckenstein J, Babcock E, Cullum CM. Hippocampal volume, spectroscopy, cognition, and mood in patients receiving corticosteroid therapy. Biol Psychiatry. 2004;55:538-545.

20. Mesripour A, Alhimma F, Hajhashemi V. The effect of vitamin B6 on dexamethasone-induced depression in mice model of despair Nutr Neurosci. 2018;24:1-6.

21. Zhao Y, Ma R, Shen J, Su H, Xing D, Du L. A mouse model of depression induced by repeated corticosterone injections. Eur J Pharmacol. 2008;581:113-120.
22. Mesripour A, Meshkati A, Hajhashemi V. A synbiotic mixture augmented the efficacy of doxepin, venlafaxine, and fluvoxamine in mice model of depression. Turk J Pharm Sci. 2020;17:293-298.

23. Ait-belgnaoui A, Colom A, Braniste V, Ramalho L, Marrot A, Cartier C, Houdeau E, Theodorou V, Tompkins T. Probiotic gut effect prevents the chronic psychological stress-induced brain activity abnormality in mice. Neurogastroenterol Motil. 2014;26:510-520.

24. Cryan JF, Markou A, Lucki I. Assessing antidepressant activity in rodents: recent developments and future needs. Trends Pharmacol Sci. 2002;23:238-245.

25. Strekalova T, Spanagel R, Bartsch D, Henn FA, Gass P. Stress-induced anhedonia in mice is associated with deficits in forced swimming and exploration. Neuropsychopharmacology 2004;29:2007-2017.

26. Rooman R, Koster G, Bloemen R, Gresnigt R, van Buul-Offers SC. The effect of dexamethasone on body and organ growth of normal and IGFII-transgenic mice. J Endocrinol. 1999;163:543-552.

27. Million M, Angelakis E, Paul M, Armougom F, Leibovici L, Raoult D. Comparative meta-analysis of the effect of Lactobacillus species on weight gain in humans and animals. Microb Pathog. 2012;53:100-108.

28. Wang J, Tang H, Zhang C, Zhao Y, Derrien M, Rocher E, van-Hylckama Vlieg JE, Strissel K, Zhao L, Obin M, Shen J. Modulation of gut microbiota during probiotic-mediated attenuation of metabolic syndrome in high fat diet-fed mice. ISME J. 2015;9:1-15.

29. Sabater-Molina M, Larqué E, Torrella F, Zamora S. Dietary fructooligosaccharides and potential benefits on health. J Physiol Biochem. 2009;65:315-328.

30. Yankelevitch-Yahav R, Franko M, Huly A, Doron R. The forced swim test as a model of depressive-like behavior. J Vis Exp. 2015;97:52587.

31. Marks W, Fournier NM, Kalynchuk LE. Repeated exposure to corticosterone increases depression-like behavior in two different versions of the forced swim test without altering nonspecific locomotor activity or muscle strength. Physiol Behav. 2009;98:67-72.

32. Johnson SA, Fournier NM, Kalynchuk LE. Effect of different doses of corticosterone on depression-like behavior and HPA axis responses to a novel stressor. Behav Brain Res. 2006;168:280-288.

33. Anacker C, Zunszain PA, Carvalho LA, Pariante CM. The glucocorticoid receptor: pivot of depression and of antidepressant treatment? Psychoneuroendocrinology. 2011;36:415-425.

34. Million M, Taché $Y$, Anton P. Susceptibility of Lewis and Fischer rats to stress-induced worsening of TNB-colitis: protective role of brain CRF. Am J Physiol. 1999;276:G1027-1036.

35. Mahar I, Bambico FR, Mechawar N, Nobrega JN. Stress, serotonin, and hippocampal neurogenesis in relation to depression and antidepressant effects. Neurosci Biobehav Rev. 2014;38:173-192.

36. Forsythe P, Sudo N, Dinan T, Taylor VH, Bienenstock J. Mood and gut feelings. Brain Behav Immun. 2010;24:9-16.

37. O'Mahony SM, Marchesi JR, Scully P, Codling C, Ceolho AM, Quigley EM, Cryan JF, Dinan TG. Early life stress alters behavior, immunity, and microbiota in rats: implications for irritable bowel syndrome and psychiatric illnesses. Biol Psychiatry. 2009;65:263-267.

38. Marks DM, Han C, Krulewicz S, Pae CU, Peindl K, Patkar AA, Masand PS. History of depressive and anxiety disorders and paroxetine response in patients with irritable bowel syndrome: post hoc analysis from a placebo-controlled study. Prim Care Companion J Clin Psychiatry. 2008;10:368-375. 